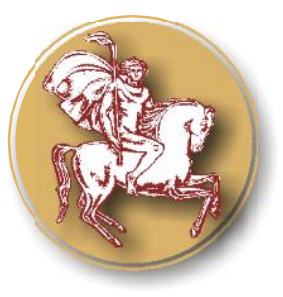

\title{
PROLACTIN RECEPTOR GENE (PRLR) ROLE IN SWINE REPRODUCTION
}

\author{
Zh. Sabev* \\ Department of Genetics, Animal Breeding and Reproduction, Agricultural Faculty, Trakia University, \\ Stara Zagora
}

\begin{abstract}
PRLR gene has been studied as a candidate gene for litter size in swine because of prolactin biological functions and their association with reproduction. Prolactin receptor gene is mapped on porcine chromosome 16. The established PCR-RFLP polymorphism at PRLR locus demonstrated the presence of two alleles, $\mathrm{A}$ and $\mathrm{B}$ and three genotypes $\mathrm{AA}, \mathrm{AB}$ and $\mathrm{BB}$. There were found different allele and genotype frequencies in different pig populations with variation of the effects of PRLR genotypes on litter traits. Additional studies should be done in specific breeds and populations to evaluate the association of existing PRLR locus polymorphism with reproductive traits before application of marker-assisted selection in these populations.
\end{abstract}

Key words: PRLR gene, polymorphism, genetic marker, litter size

Intensive and efficient pork production implies improved production traits - growth traits, carcass and meat quality traits, but also needs sows with high reproductive potential and substantial survival rates of pigs $(1,2)$.

Because of low heritability of litter size traits in swine, efficient approach in genetic improvement of these traits is application of marker-assisted selection (MAS) alongside with classical selective breeding, (3).

Ernst and Steibel affirmed that a candidate gene is a gene, identified on the basis of its physiological function or genome location, that potentially controls part of variation of a specific trait (4). The advances in genome studies in swine allowed for identification of quantitative trait loci (QTL) and genes involved in the genetic control of meat production and reproduction traits (5 - 12).

Biochemical functions of prolactin and the PRLR gene and mapping in pigs

Prolactin (PRL) is a peptide hormone

*Correspondence to: Zh. Sabev, Trakia University, Agricultural faculty, Dept. Genetics, Animal breeding and Reproduction - Stara Zagora, zhsabev@uni-sz.bg discovered a century ago $(13,14)$. The synthesis and release of the hormone from the anterior pituitary is under negative control by dopamine (15), which binds to surface prolactin receptors in target tissues. Prolactin is detected in different tissues and cells and its concentrations vary during the estrus, pregnancy and lactation (16-18). It is essential for the formation and differentiation of mammary epithelial cells during the gestation (19). Blood prolactin levels in pregnant sows are usually low but become increased in the per parturient period and lactation (20). Active prolactin binds to specific surface prolactin receptors (PRLRs) encoded by the prolactin receptor gene (PRLR) and controls intracellular protein activity $(21,22)$. Prolactin becomes active after binding to PRLRs, and the latter are essential for various events connected with reproduction as mammary gland development, lactation and maternal behavior (23).

Bole-Feysot et al., reported that prolactin is involved in hundreds biochemical reactions with direct relationships with estrogens in prepubertal swine and with PRLR-mediated changes in ovaries and the uterus. This hormone regulates luteal and follicular estrus 
stages in sows and plays a primary role in maintaining the functions of yellow body. By the end of lactation in sows or after piglets weaning, prolactin influences the cyclic ovarian activity and the estrus onset (24). Furthermore it has an influence on progesterone and relaxin hormones production in the presence of prolactin receptors in endometrial cells of sows, and this effect is associated to gestational age $(25,26)$. This presumes a possible prolactin role in the preparation and maintenance of gestation in sows. Based on physiological effects expressed at fertilization and gestation and its complex role in a number of reproductive events, the PRLR gene is accepted as a candidate gene associated with litter size traits in sows $(28$ 30). The PRLR gene is mapped on chromosome 16 in swine $16 \mathrm{q} 1.4$ or $16 \mathrm{q} 2.2$ 2.3 (31). The location of PRLR gene is presented on region of the physical map of the porcine chromosome 16 (Figure 1).

\section{Chromosome 16: 20,637,568-20,655,881}
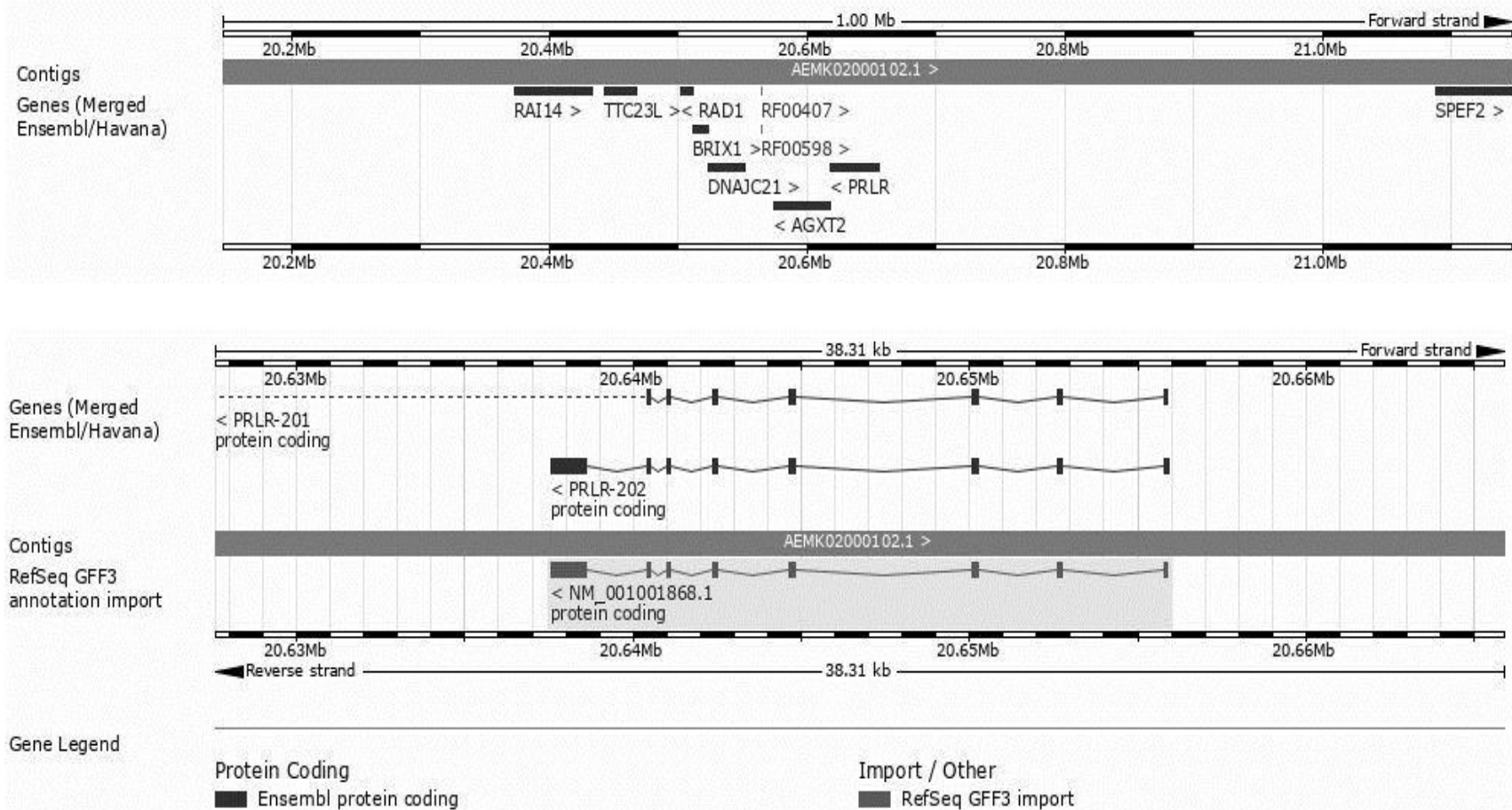

Figure 1. Physical map of porcine chromosome 16 region with the PRLR locus.

(http://www.ensembl.org/Sus_scrofa/Gene/Summary?db=otherfeatures;g=414916;r=16:20637568-

20655881;t=NM_001001868.1).

\section{Polymorphism at the porcine PRLR locus}

The AluI polymorphism in the porcine PRLR gene and its effects on litter size were studied first by Vincent et al. and Rothschild et al. (31, 32). This established PCR-RFLP genetic polymorphism at the PRLR locus demonstrated the presence of two alleles $A$ and $\mathrm{B}$ and three genotypes ( $\mathrm{AA}, \mathrm{AB}$ and $\mathrm{BB}$ ) with varying frequencies in the different swine populations $(27,33)$. In Large White, Landrace and crossbred sows, Mihailov et al., found PRLR allele frequencies of $0.33,0.58$ and 0.52 respectively for allele $\mathrm{A}$ and $0.66,0.41$ and 0.47 for allele B (34). In another study, allele A frequencies were found to be relatively similar in Large White and Landrace sows, with genotype frequencies of 0.24 and 0.18 for the homozygous genotype AA; 0.48 and 0.57 for the heterozygous genotype $\mathrm{AB} ; 0.28$ and 0.25 for the homozygous genotype BB (2). In Mangalica $\times$ Duroc crosses, similar frequencies of alleles A and B were found (0.52 and 0.48), with relatively lower frequencies of homozygous AA and BB genotypes (0.18; 0.15 ) and comparatively higher frequency of the heterozygous $\mathrm{AB}$ genotype -0.67 (35). In Large White sows, Liu et al., estimated allele $B$ frequency of 0.54 that was higher than that of allele A -0.46 (36). Close results were found for the wild boar and Large White crosses, with lower frequency of allele A (0.44) versus that of allele B (0.56) and predominance of the frequency of the heterozygous PRLR AB genotype: 0.51, as 
compared to those of both homozygous genotypes - 0.19 for PRLR AA and 0.30 for PRLR BB (37). Another study in different pig breeds established higher frequency for allele A in Hungarian Large White and Pietrain breeds (0.63 and 0.59 respectively) than for allele B frequency ( 0.37 and 0.41$)$. In the same study Duroc sows, allele A frequency was lower than that of allele B (0.17 vs 0.83$)$ (38).

\section{Association of porcine PRLR gene polymorphism with reproduction traits}

Vincent et al., reported the PRLR-AluI gene polymorphism (allele A) association with bigger litter size at birth in Large White, Landrace, Duroc $\times$ Large White and Large White $\times$ Meishan crosses (39). PRLR gene allele $\mathrm{A}$ additive genetic effects on sows litter traits were found in six PIC lines $(22,32)$, in Large White, Landrace, Meishan (40) and Duroc breeds (30). Sows, F2 crosses of Large White $\times$ Meishan, with PRLR AA genotype, were significantly better for number of total born and live born piglets compared to sows from the other two PRLR genotypes (22). Similar results were found in study of crossbred sows Polish Large White $\times$ Landrace (28). The PRLR AluI polymorphism was found to be associated with first parity litter size at birth in sows from the Landrace breed whereas the PRLR HpaII polymorphism - with the litter size at weaning in both Landrace and Large White lines (41). Results of Wang et al., pointed that first parity Beijing Black sows with PRLR AA genotype were slightly better with respect to the total number born and liveborn pigs, but not significant to the other two genotypes (42). The authors however, reported significantly higher total number born and number of live-born pigs for next parities.

Another studies on the problem showed that the PRLR genotype favorably associated with litter size traits could be different for sows from different breeds and lines $(43,44)$.

In addition, to the studies on the effects of polymorphism at the PRLR gene on litter traits in sows, many studies have been focused on its influence on reproductive traits in boars. Kmiec and Terman found that the genotype PRLR AB boars were with significantly greater ejaculate volume, higher spermatozoa concentrations, live spermatozoa percentages and number in ejaculate compared to boars from the homozygous PRLR AA and PRLR BB genotypes (46). Similarly, Huang et al. reported similar effect on semen quality, ejaculate volume, spermatozoa concentrations, and number/percentage of live spermatozoa in the ejaculate (46), but in another study (47) results did not pointed for the presence of any significant effects of PRLR genotypes on semen quality and fertility traits in boars.

\section{Association of porcine PRLR gene polymorphism with meat production traits}

The primary breeding goals in pig breeding programs are meat production traits - growth, carcass and meat quality traits. The proper application of genetic markers with regard to improvement of reproductive traits of swine, their associations with meat production traits should be also considered. This is especially important to avoid potential contradictory effects of genetic markers associated with reproduction on pork production traits. In this sense, a beneficial effect of PRLR allele A was found in terms of lower backfat thickness, less days to $90 \mathrm{~kg}$ weight and increased average daily weight gain in Berkshire pigs (48). Similar results found by Mihailov et al., confirmed that PRLR genotype AA had better meat production traits in crossbred pigs (34). In a study on Mangalica $\times$ Duroc crosses, no pleiotropic effects of PRLR genotypes on production traits were demonstrated (35).

In conclusion, presented results provide evidence for a substantial variation of PRLR allele and genotype frequencies in populations of various pig breeds and lines. Along with the variable effect of PRLR genotypes on litter traits in different pig populations and the lack of antagonistic effect on primary production traits in pig populations, the PRLR gene seems promising as genetic marker of reproductive traits. Additional studies should be done in specific breeds and populations to evaluate the association of existing polymorphism at PRLR locus with reproduction traits before application of marker-assisted selection in these populations.

\section{REFERENCES}

1. Kováč, G., Tothova, C. S., Nagy, O., Seidel, H., Acute phase proteins during the reproductive cycle of sows. Acta Veterinaria, 58(5-6), 459-466, 2008.

2. Omelka, R., Martiniaková, M., Peskovicova, D., Bauerová, M., Associations between Alu I polymorphism in the prolactin receptor gene and reproductive traits of Slovak large white, white meaty and landrace pigs. Asian Australasian Journal of Animal Sciences, 21(4), 484, 2008. 
3. Dekkers, J. C., Commercial application of marker-and gene-assisted selection in livestock: Strategies and lessons 1 2. Journal of Animal Science, 82(13_suppl), E313-E328, 2004.

4. Ernst, C. W., Steibel, J. P., Molecular advances in QTL discovery and application in pig breeding. Trends in Genetics, 29(4), 215-224, 2013.

5. Wang, X., Wang, A., Fu, J., Lin, H., Effects of ESR1, FSHB and RBP4 genes on litter size in a Large White and a Landrace Herd. Archives Animal Breeding, 49(1), 64-70, 2006.

6. Terman, A., Kmiec, M., Polasik, D., Pradziadowicz, K., Retinol binding protein 4 gene and reproductive traits in pigs. Archives Animal Breeding, 50, 181-185, 2007.

7. Linville, R. C., Pomp, D., Johnson, R. K., Rothschild, M. F., Candidate gene analysis for loci affecting litter size and ovulation rate in swine. Journal of Animal Science, 79(1), 60-67, 2001.

8. Droegemüller, C., Hamann, H., Thieven, U., Krieter, J., Distl, O., Harlizius, B., Influence of the genome region surrounding the estrogen receptor (ESR) gene on litter size in a German Landrace population. Archives Animal Breeding, 42, 175-177, 1999.

9. Rothschild, M. F., Candidate gene analysis to detect genes controlling traits of economic importance in domestic livestock. Probe Newsletter for Agriculture Genomics, 8(2), 13-20, 1997.

10.Maćkowski, M., Świtoński, M., Maćkowska, J.; Perz, W., Polymorphism of the GPX-5 gene and characteristics of boar semen. Archives Animal Breeding, 47, 2, 165-171, 2004.

11.Schlingmann, C., Dietl, G., Räder, I., Association von Polymorphismen im Promotbereich des porcinen HSP 70.2-Gens bei Ebern mit der Wurfgrősse. Archives Animal Breeding, 45, 2, 171-180, 2002.

12.Kmieć, M., Dybus, A., Terman, A., Prolactin receptor gene polymorphism and its association with litter size in Polish Landrace. Archives Animal Breeding, 44, 5, 547-551, 2001.

13.Stricker P. and Grueter R., Action du lobe antrerieur de Lhypophyse sur la montee laiteuse. Comptes Rendus des Seances de la Societe de Biologie et de ses Filiales, 99, 1978-1980, 1928.
14.Riddle, O., Bates, R. W., Dykshorn, S. W., The preparation, identification and assay of prolactin - a hormone of the anterior pituitary. American Journal of Physiology Legacy Content, 105(1), 191-216, 1933.

15.Ben-Jonathan, N., Hnasko, R., Dopamine as a prolactin (PRL) inhibitor. Endocrine Reviews, 22(6), 724-763, 2001.

16.Jahn, G. A., Edery, M., Belair, L., Kelly, P. A., Djiane, J., Prolactin receptor gene expression in rat mammary gland and liver during pregnancy and lactation. Endocrinology, 128(6), 29762984, 1991.

17.Hovey, R. C., Trott, J. F., Ginsburg, E., Goldhar, A., Sasaki, M. M., Fountain, S. J., Vonderhaar, B. K., Transcriptional and spatiotemporal regulation of prolactin receptor mRNA and cooperativity with progesterone receptor function during ductal branch growth in the mammary gland. Developmental Dynamics, 222(2), 192-205, 2001.

18.Trott, J. F., Horigan, K. C., Gloviczki, J. M., Costa, K. M., Freking, B. A., Farmer, C., Hovey, R. C., Tissue-specific regulation of porcine prolactin receptor expression by estrogen, progesterone, and prolactin. Journal Endocrinology, 202(1), 153-166, 2009.

19.Tucker, H. A., Hormones, Mammary Growth, and Lactation: a 41-Year Perspective1. Journal of Dairy Science, 83(4), 874-884.

20.DeHoff, M. H., Stoner, C. S., Bazer, F. W., Collier, R. J., Kraeling, R. R., Buonomo, F. C., Temporal changes in steroids, prolactin and growth hormone in pregnant and pseudopregnant gilts during mammogenesis and lactogenesis. Domestic Animal Endocrinology, 3(2), 95-105, 1986.

21. Ormandy, C. J., Camus, A., Barra, J., Damotte, D., Lucas, B., Buteau, H., Kelly, P. A., Null mutation of the prolactin receptor gene produces multiple reproductive defects in the mouse. Genes \& Development, 11(2), 167-178, 1997.

22.van Rens, B. T., Evans, G. J., van der Lende, T., Components of litter size in gilts with different prolactin receptor genotypes. Theriogenology, 59(3), 915-926, 2003.

23.Farmer, C., Sorensen, M. T., Petitclerc, D., Inhibition of prolactin in the last trimester of gestation decreases mammary gland development in gilts. Journal of Animal Science, 78(5), 1303-1309, 2000. 
24.Bole-Feysot, C., Goffin, V., Edery, M., Binart, N., Kelly, P. A., Prolactin (PRL) and its receptor: actions, signal transduction pathways and phenotypes observed in PRL receptor knockout mice. Endocrine Reviews, 19(3), 225-268, 1998.

25.Freeman, M. E., Kanyicska, B., Lerant, A., Nagy, G., Prolactin: structure, function, and regulation of secretion. Physiological Reviews, 80(4), 1523-1631, 2000.

26.Li, X. P., Shi, Q. S., Liu, X. C., Tang, F., Zhang, D. J., The Effect of PRLR Gene to Litter Size in Large White and Landrace Pigs [J]. Swine Production, 6, 19-20, 2005.

27.Serrano, A. B., Haro, J. H., Hori-Oshima, S., Espinosa, A. G., Cerrilla, M. O., Perez, J. P., Productividad-Ganadería, P. R. G., Prolactin receptor (PRLR) gen polymorphism and associations with reproductive traits in Pigs. Journal of Animal and Veterinary Advances, 8(3), 469-475, 2009.

28.Terman, A., Effect of the polymorphism of prolactin receptor (PRLR) and leptin (LEP) genes on litter size in Polish pigs. Journal of Animal Breeding and Genetics, 122(6), 400-404, 2005.

29.van Rens, B. T., van der Lende, T., Litter size and piglet traits of gilts with different prolactin receptor genotypes. Theriogenology, 57(2), 883-893, 2002.

30.Drogemuller, C., Hamann, H., Distl, O., Candidate gene markers for litter size in different German pig lines. Journal of Animal Science, 79(10), 2565-2570, 2001.

31. Vincent, A. L., Wang, L., Tuggle, C. K., Robic, A., Rothschild, M. F., Prolactin receptor maps to pig chromosome 16. Mammalian Genome, 8(10), 793-794, 1997.

32.Rothschild, M. F., Vincent, A. L., Tuggle, C. K., Evans, G., Short, T. H., Southwood, O. I., Plastow, G. S., A mutation in the prolactin receptor gene is associated with increased litter size in pigs. Animal Genetics,Suppl., 29, 69, 1998.

33.Kmieć, M., Terman, A., Associations between the prolactin receptor gene polymorphism and reproductive traits of boars. Journal of Applied Genetics, 47(2), 139-141, 2006.

34.Mihailov, N. V., Usatov, A. V., Getmantseva, L. V., Bakoev, S. U., Associations between PRLR/AluI gene polymorphism with reproductive, growth, and meat traits in pigs. Cytology and Genetics, 48(5), 323-326, 2014.
35.Tempfli, K., Simon, Z., Kovács, B., Posgay, M., Bali Papp, Á., PRLR, MC4R and LEP polymorphisms, and ADIPOQ, AFABP and LEP expression in crossbred mangalica pigs. The Journal of Animal and Plant Science, 25(6), 1746-1752, 2015.

36.Liu, Y., Li, L. L., Mo, X. Y., Wang, J. H., Xiong, Y. Z., Lei, M. G., Polymorphism of PRLR, RBP4 Gene and the Relationship between Polymorphisms and Litter Size in Large White [J]. China Animal Husbandry and Veterinary Medicine, 7, 035, 2010.

37.Zhang, D. J., Liu, D., Yang, G. W., Fu, X. K., He, X. M., Impact of the GPX5, FUT1, FSH $\beta$ and PRLR genes on individual weight at birth and 30 days in hybrid pig. Journal of Applied Animal Research, 38(2), 239-243, 2010.

38.Balogh, P., Nagy, K., Kusza, S., Association and polymorphism study of seven candidate genes with reproductive traits in three pig breeds in Hungary. Acta Biochimica Polonica, 63(2), 2016.

39. Vincent, A. L., Tuggle, C. K., Rothschild, M. F., Evans, G., Short, T. H., Southwood, O. I., Plastow, G. S., The prolactin receptor gene is associated with increased litter size in pigs. Animal Science Research Reports, ISU, 1998.

40.Southwood O., Short T., Plastow G., Rothschild M., A genetic marker for litter size in Landrace-based pig lines. EAAP, Zurich 22-26 August 5, 1, 1999.

41.Putnova, L., Knoll, A.,. Dvorak, J. and Cepica, S., A new HpaII PCR-RFLP within the porcine prolactin receptor (PRLR) gene and study of its effect on litter size and number of teats. Journal of Animal Breeding and Geneics. 119:57-63, 2002.

42.Wang, X., Wang, L., Luo, R., Sun, S., Analysis of PRLR and BF genotypes associated with litter size in Beijing black pig population. Agnc. Sci. China, 7: 13741378, 2008.

43.Fan, B., Onteru, S. K., Nikkilä, M. T., Stalder, K. J., Rothschild, M. F., Identification of genetic markers associated with fatness and leg weakness traits in the pig. Animal Genetics, 40(6), 967-970, 2009.

44.Karagodina, N., Kolosov, Y., Bakoev, S., Kolosov, A., Leonova, M., Shirokova, N., Usatov, A., Influence of various biostimulants on the biochemical and hematological parameters in porcine blood plasma. World Applied Sciences Journal, 30(6), 723-726, 2014. 
45.Kmieć, M., Terman, A., Associations between the prolactin receptor gene polymorphism and reproductive traits of boars. Journal of Applied Genetics, 47(2), 139-141, 2006.

46.Huang, S. Y., Song, H. L., Lin, E., Lee, W. C., Chiang, J. C., Tsou, H. L., Association of polymorphisms in epidermal growth factor, prostaglandin-endoperoxide synthase 2 and prolactin receptor genes with semen quality in duroc boars. Asian Australasian Journal of Animal Sciences, 19(6), 793, 2006.
47.Lin, C. G., Zhu, Z. M., Li, S. L., Chen, H., Zheng, N. Z., Miao, Z. W., Ye, X. H., Relationship between Alu I polymorphism of PRLR gene and reproduction trait of swine. Fujian Journal of Agricultural Sciences, 23(2), 137-140, 2008.

48.Do, C. H., Cho, B. W., Lee, D. H., Study on the prolactin receptor 3 (PRLR3) gene and the retinol-binding protein 4 (RBP4) gene as candidate genes for production traits in Berkshire pigs. Asian Australasian Journal of Animal Sciences, 25(2), 183, 2012. 